\title{
Un "Document technographique" : le devis
}

Marine royale et fortifications aux XVIIe et XVIIIe siècles

\section{Hélène Vérin}

\section{OpenEdition}

\section{Journals}

Édition électronique

URL : https://journals.openedition.org/tc/868

DOI : $10.4000 /$ tc. 868

ISSN : 1952-420X

Éditeur

Éditions de l'EHESS

\section{Édition imprimée}

Date de publication : 1 septembre 1987

ISSN : 0248-6016

Référence électronique

Hélène Vérin, «Un "Document technographique" : le devis », Techniques \& Culture [En ligne], 9 | 1987, mis en ligne le 23 janvier 2006, consulté le 29 septembre 2022. URL : http://journals.openedition.org/ tc/868 ; DOI : https://doi.org/10.4000/tc.868

Ce document a été généré automatiquement le 29 septembre 2022.

Tous droits réservés 


\section{Un "Document technographique" : le devis}

Marine royale et fortifications aux XVIIe et XVIIIe siècles

Hélène Vérin 